\title{
Molecular Medicine
}

National Cancer Institute

\section{Source}

National Cancer Institute. Molecular Medicine. NCI Thesaurus. Code C18885.

The branch of medicine that tries to understand disease processes by understanding the way that genes, proteins, and molecules interact; also concerned with genetically based treatments. 